\title{
A new genus and species of proteocephalidean tapeworm (Cestoda), first parasite found in the driftwood catfish Tocantinsia piresi (Siluriformes: Auchenipteridae) from Brazil
}

\author{
Philippe Vieira Alves ${ }^{1}$, Alain de Chambrier ${ }^{2}$, Tomáš Scholz ${ }^{3}$ and José Luis Luque ${ }^{4}$ \\ ${ }^{1}$ Programa de Pós-Graduação em Biologia Animal, Universidade Federal Rural do Rio de Janeiro, Seropédica, Rio de Janeiro, Brazil; \\ ${ }^{2}$ Department of Invertebrates, Natural History Museum, Geneva, Switzerland; \\ ${ }^{3}$ Institute of Parasitology, Biology Centre of the Czech Academy of Sciences, České Budějovice, Czech Republic; \\ ${ }^{4}$ Departamento de Parasitologia Animal, Universidade Federal Rural do Rio de Janeiro, Seropédica, Rio de Janeiro, Brazil
}

\begin{abstract}
Frezella gen. n. is proposed to accommodate Frezella vaucheri sp. n. from poorly known auchenipterid fish, Tocantinsia piresi (Miranda Ribeiro), from the Xingú River, one of the principal tributaries of the lower Amazon River in Brazil. The new genus belongs to the Proteocephalinae because of the medullary position of the testes, ovary (yet some follicles penetrate to the cortex on the dorsal side), vitelline follicles and uterus. It differs from other proteocephaline genera in the morphology of the scolex, which includes a metascolex composed of two distinct zones: anterior, strongly wrinkled part posterior to the suckers, and posterior, sparsely folded zone. Frezella can also be differentiated by having the internal longitudinal musculature hypertrophied laterally on both sides, the presence of some ovarian follicles in the cortex on the dorsal side and the presence of additional pair of tiny, thin-walled osmoregulatory canals situated slightly dorsomedian to ventral canals. Frezella vaucheri is the first helminth parasite reported from T. piresi, which occurs in the lower reaches of the Amazon and Tocantins River basins in Brazil.
\end{abstract}

Keywords: taxonomy, morphology, Proteocephalidea, metascolex, Amazon River basin, Xingú River, Neotropical Region

The Neotropical region hosts the highest diversity of freshwater fishes on the Earth (Reis 2013). Siluriforms (catfishes) represent one of the dominant groups of the fish fauna of this region and some of them serve as definitive hosts of proteocephalidean tapeworms (Eucestoda: Proteocephalidea). The highest diversity of tapeworm species was recognised in large pimelodids such as Brachyplatystoma Bleeker, Phractocephalus Agassiz, Pseudoplatystoma Bleeker and Zungaro Bleeker in the Amazon and Paraná River basins. Some species of these genera may host as many as 7-9 species of proteocephalideans (de Chambrier and Vaucher 1999, Rego et al. 1999, de Chambrier et al. 2006, 2014, Arredondo et al. 2013, 2014). However, proteocephalidean cestodes also parasitise other groups of siluriforms, such as auchenipterids, in particular species of Ageneiosus Lacépède (see de Chambrier and Vaucher 1999, Gil de Pertierra 2009).

During studies on the parasitic helminths of freshwater fishes from the Xingú River (southern tributary of the Amazon River) in Brazil, proteocephalidean tapeworms were found in the intestine of the auchenipterid catfish Tocantinsia piresi (Miranda Ribeiro), locally known as 'pocomão'. This fish was described as Glanidium piresi by Miranda Ribeiro (1920) from the São Manuel River, which forms, together with the Juruena River, the Tapajós River (one of the principal southern tributaries of the Amazon River). Much later, Mees (1974) proposed a new genus, Tocantinsia Mees, to accommodate his new species $T$. depressa Mees from the Tocantins River, i.e. another river basin independent to that of the Amazon River. However, the same author (Mees 1984) synonymised Tocantinsia depressa with Glanidium piresi, which actually does not belong to Glanidium Lütken. Therefore, a new combination, T. piresi, was proposed by Mees (1984) and it is currently accepted as valid name (Froese and Pauly 2014). This fish occurs in both the Amazon and Tocantins River basins (Barros 2012), but data on its parasites including proteocephalidean cestodes are absent.

Morphological evaluation of the cestodes found in T. piresi from the Xingú River has revealed that they represent a new species, which is described herein. In addition, the new species cannot be allocated to any of the known genera of proteocephalidean cestodes. Therefore, a new genus is proposed to accommodate this new species.

Address for correspondence: T. Scholz, Institute of Parasitology, Biology Centre of the Czech Academy of Sciences, Branišovská 31 , 370 05 České Budějovice, Czech Republic. Phone: +420 38777 5431; Fax: +420 38531 0388; E-mail: tscholz@paru.cas.cz 


\section{MATERIALS AND METHODS}

Fish collected by local fishermen were kept alive in a box filled with fresh water prior to being transported to the laboratory and then immediately dissected. Cestodes found were placed in saline. Out of the nine specimens found, five were fixed with hot $4 \%$ neutral formaldehyde solution and subsequently stored in $70 \%$ ethanol (see de Chambrier et al. 2014). A small piece of the posterior end of the four remaining specimens was cut off and placed in molecular-grade $96-99 \%$ ethanol for sequencing of the 28S rRNA gene (for methodology, see Ash et al. 2012). For morphology, specimens were stained with Mayer's hydrochloric carmine solution, dehydrated in an ethanol series, cleared with eugenol (clove oil) and mounted in Canada balsam. Pieces of the strobila were embedded in paraffin wax, cross sectioned at $12-15 \mu \mathrm{m}$, stained with Weigert's haematoxylin and counterstained with $1 \%$ eosin B following protocol outlined by de Chambrier (2001).

For scanning electron microscopical (SEM) observations, scoleces of the new species were prepared by the method described by Oros et al. (2010) and observed with a Zeiss 940a electron microscope at the Natural History Museum, Geneva and JEOL JSM 6700F scanning electron microscope at the Institute of Parasitology, BC CAS, České Budějovice, Czech Republic. Microthrix terminology follows Chervy (2009). All measurements are given in micrometres unless otherwise indicated. Abbreviations used in descriptions are as follows: $\mathrm{x}$ - mean; $\mathrm{n}$ - number of measurements. Acronyms of collections: CHIOC - Helminthological Collection of the Instituto Oswaldo Cruz, Rio de Janeiro, Brazil; IPCAS - Institute of Parasitology, České Budějovice, Czech Republic; MHNG-PLAT - Natural History Museum, Geneva, Switzerland.

\section{RESULTS}

Frezella gen. n.

\section{ZooBank number for genus:}

urn:1sid:zoobank.org:act:1396D02F-CD2A-

4A24-9BC8-E01A37E33AA4

Diagnosis: Proteocephalidea, Proteocephalidae, Proteocephalinae. Medium-sized, robust worms. Strobila acraspedote, with proglottids variable in shape and size. Apex of scolex with muscular apical organ and metascolex composed of 2 distinct zones; anterior part strongly wrinkled, posterior part with few longitudinal wrinkles. Suckers uniloculate. Internal longitudinal musculature well developed, with bundles of muscle fibres forming conspicuous concentrations on lateral sides of proglottids. A pair of tiny, thin-walled osmoregulatory canals situated slightly dorsomedian to ventral canals. Testes medullary, numerous, in 3 fields and 1-3 irregular layers. Vitelline follicles medullary, in 2 lateral bands. Vagina posterior or anterior to cirrus-sac; vaginal sphincter present. Genital pore alternating irregularly, pre-equatorial. Ovary medullary, slightly folliculate, bilobed, with a few lobes on dorsal side penetrating to cortex. Uterine stem medullary. Uterine development of type 1 sensu de Chambrier et al. (2004a). Precocious uterine aperture present. Parasites of Neotropical siluriform fish (Auchenipteridae).
Type and only species: Frezella vaucheri sp. n.

Ety mology: This genus is named in honour of the late Vadim I. Freze, Russia, for his outstanding contribution to the systematics and biology of proteocephalidean cestodes. The name should be treated as femininum.

Differential diagnosis. The new genus belongs to the Proteocephalinae because of the medullary position of testes, ovary (with some lobes penetrating to the cortex on the dorsal side), vitelline follicles and uterus (Schmidt 1986, Rego 1994). To date, the subfamily includes 16 genera parasitising vertebrates of several groups (genera from Neotropical catfishes indicated by an asterisk), namely Barsonella de Chambrier, Scholz, Beletew et Mariaux, 2009; *Brayela Rego, 1984; *Cangatiella Pavanelli et Machado dos Santos, 1991; *Euzetiella de Chambrier, Rego et Vaucher, 1999; Glanitaenia de Chambrier, Zehnder, Vaucher et Mariaux, 2004; *Margaritaella Arredondo et Gil de Pertierra, 2012; *Proteocephalus Weinland, 1858; *Pseudocrepidobothrium Rego et Ivanov, 2001; and *Scholzia de Chambrier, Rego et Gil de Pertierra, 2005, all parasitic in fish; Cairaella Coquille et de Chambrier, 2008; Crepidobothrium Monticelli, 1900; Deblocktaenia Odening, 1963; Macrobothriotaenia Freze, 1965; Ophiotaenia La Rue, 1911; and Tejidotaenia Freze, 1965, all parasitising amphibians and reptiles; and Thaumasioscolex Cañeda-Guzmán, de Chambrier et Scholz, 2001, a parasite of the black-eared opossum Didelphis marsupilis Linnaeus (Mammalia) (Rego 1994, Cañeda-Guzmán et al. 2001, Arredondo and Gil de Pertierra 2012).

Frezella gen. n. differs from the above-mentioned genera in the morphology of the scolex, which includes a conical part with a muscular apical organ followed by a metascolex composed from two distinct zones: anterior, strongly wrinkled part posterior to uniloculate suckers, and posterior part with a few, deep longitudinal wrinkles (Figs. 1, 3, 9). Frezella can also be distinguished from the other proteocephalidean genera by the distribution of bundles of muscle fibres of the internal longitudinal musculature, with their conspicuous concentration on the lateral sides of proglottids (Figs. 13-17), by the penetration of some dorsal ovarian lobes to the cortex (Fig. 15), and the presence of additional pair of tiny, thin-walled osmoregulatory canals situated slightly dorsomedian to ventral canals (Fig. 12).

\section{Frezella vaucheri gen. $\mathrm{n}$. et $\mathrm{sp} . \mathrm{n}$.}

Figs. 1-18

\section{ZooBank number for species:}

urn:1sid:zoobank.org:act:8C9996CC-8CA2-42FF-B9F9-4912584125E7

Description (based on 9 specimens): Proteocephalidae, Proteocephalinae. Testes, vitelline follicles and uterus medullary; ovary medullary, with a few follicles slightly penetrating to cortex. Total body length 112-122 mm $(\mathrm{n}=3)$, maximum width up to $2.82 \mathrm{~mm}(\mathrm{n}=3)$. Strobila acraspedote, anapolytic, consisting of about 325-375 proglottids: 252-280 immature (up to appearance of spermatozoa in vas deferens), 21-23 mature (up to appearance of eggs in uterus), 52-72 pregravid (up to appearance of 


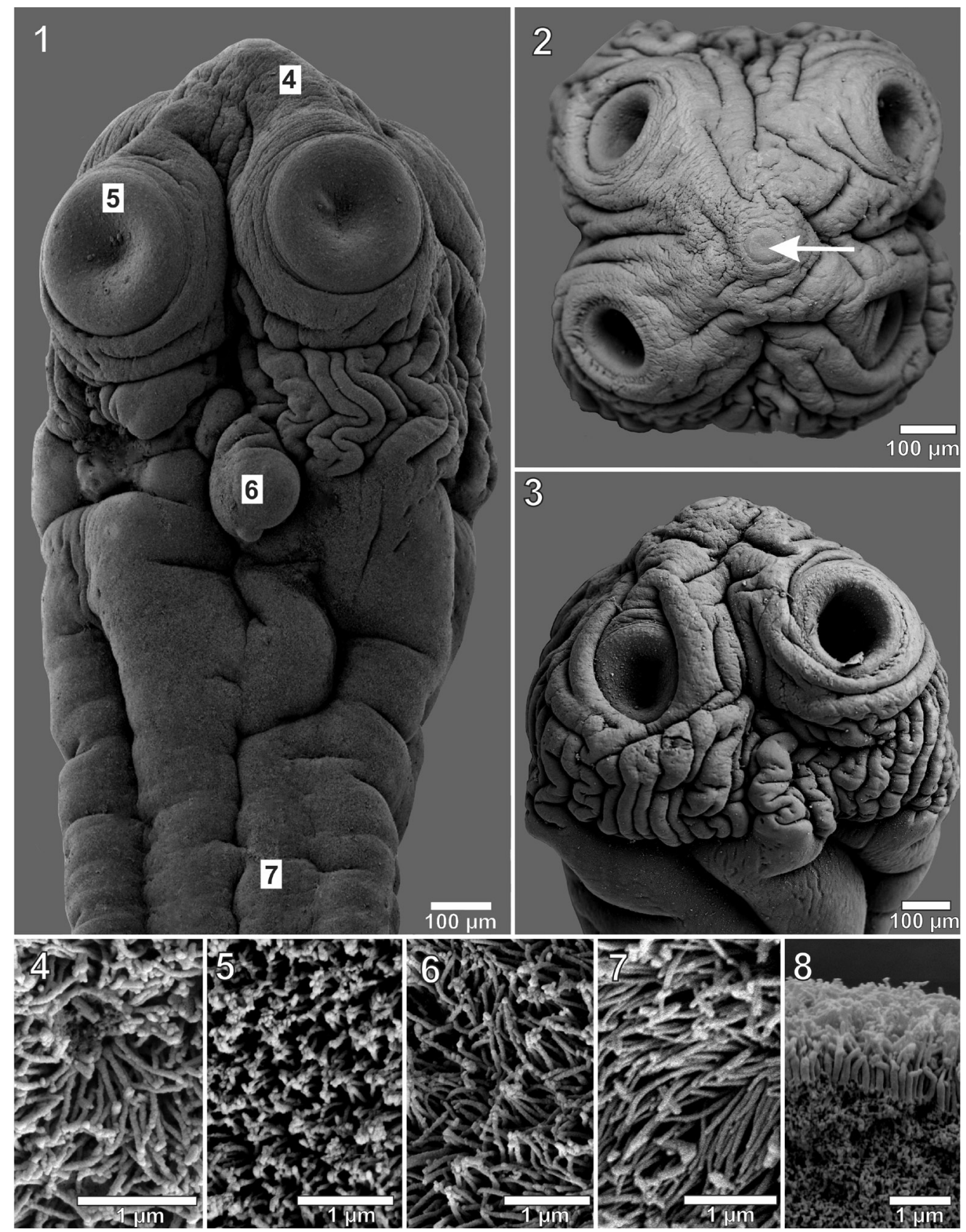

Figs. 1-8. Frezella vaucheri gen. n. et sp. n. from Tocantinsia piresi from Brazil. Scanning electron micrographs. Fig. 1. Scolex (BrX 65c-MHNG-PLAT 86718), dorsoventral view. Figs. 2, 3. Scolex, apical and lateral view, respectively; paratype (BrX 65y - IPCAS C-663); white arrow shows the orifice of the apical organ. Figs. 4-7. Capilliform filitriches on surface of upper part of apex, internal surface of suckers, anterior part of metascolex and proliferation zone (neck), respectively (BrX 65c - IPCAS C-663). Fig. 8. Acicular filitriches on surface of pregravid proglottids (BrX 65c - IPCAS C-663).

hooks in oncospheres); gravid proglottids present in some isolated pieces of strobila. Immature proglottids wider than long (length: width ratio $0.13-0.22$ ), mature and pregravid proglottids wider than long (length: width ratio 0.12-0.60).

Scolex 1 110-1575 long and 1040-1330 wide $(n=3)$, much wider than neck (width of scoleces studied using SEM 700-850; see Figs. 1-3), with metascolex composed of 2 different parts and conical apical end. Apical part short, slightly folded, with subspherical muscular apical organ, 55-90 long $\times$ 65-90 wide, group of small gland cells and network of osmoregulatory canals (Fig. 10). Middle part of scolex with 4 spherical uniloculate suckers and metascolex formed by numerous (several tens) longitudinal folds posterior to suckers, 300-355 long (Figs. 1, 3, 9); using SEM 210-290 long. Suckers spherical, 315-375 $(n=12)$ in diameter, with deep cavity and concentration of muscle fibres near their opening (Fig. 10); anterior and posterior margin with circular musculature (Fig. 10). Posterior part of scolex formed by metascolex with a few (2-3 on each side) deep longitudinal folds 395-660 long (Figs. 1, 3, 9). Neck (proliferation zone) with transverse folds, 645-1250 wide (Figs. 1, 9). Apex of scolex, sucker cavities, anterior part of metascolex and proliferation zone covered with capilliform filitriches of similar appearance 
9

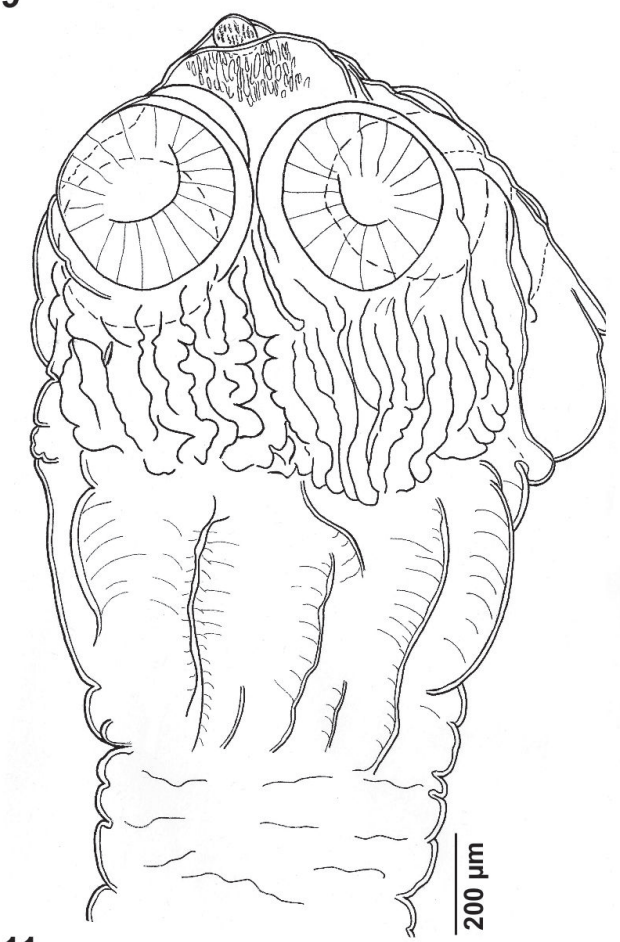

10

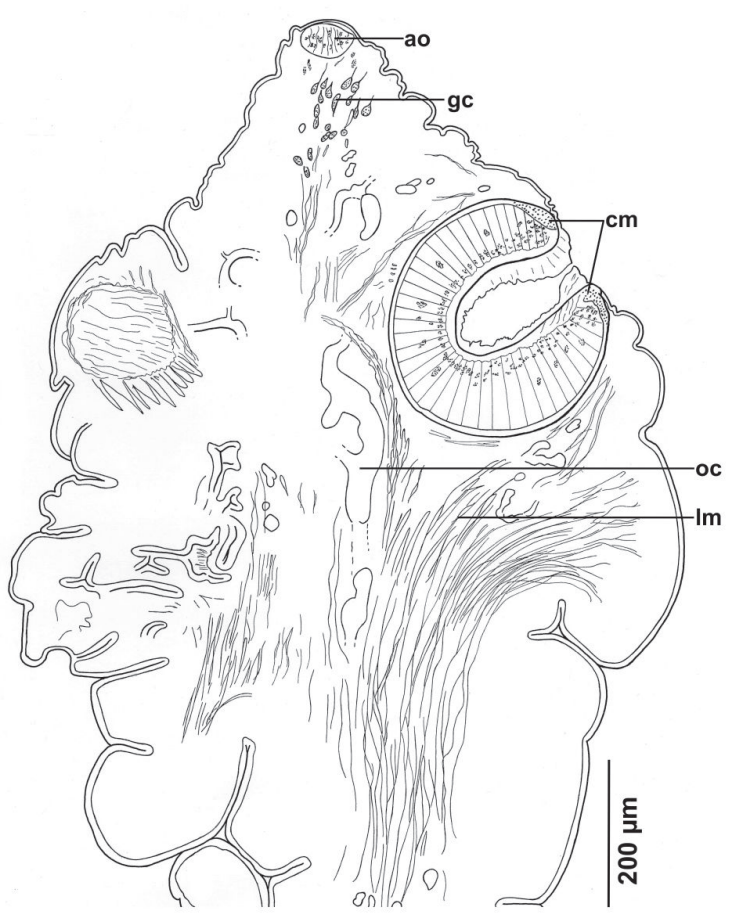

11

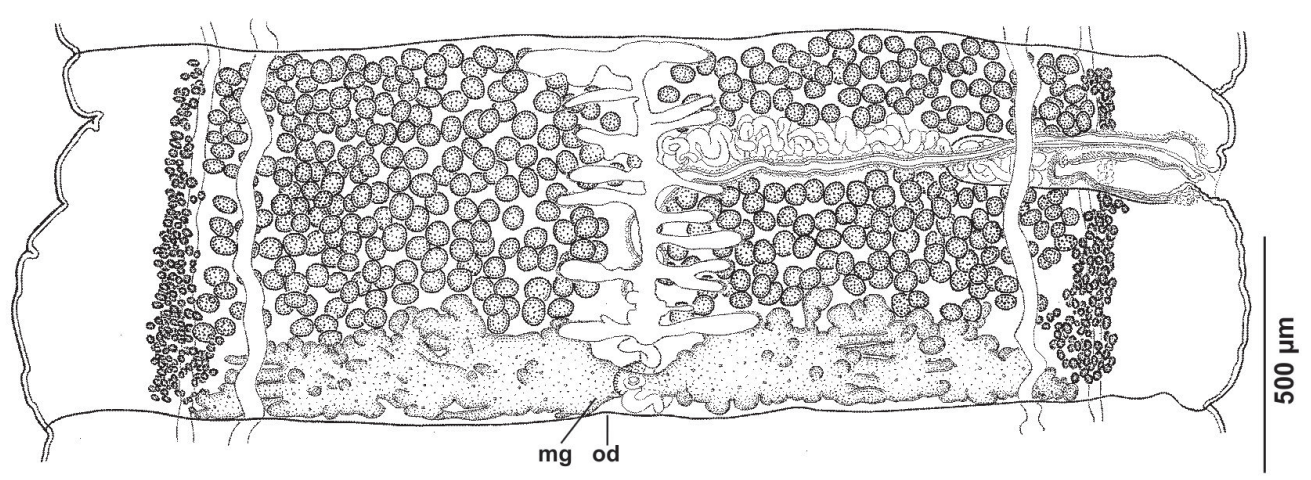

Figs. 9-11. Frezella vaucheri gen. n. et sp. n. from Tocantinsia piresi from Brazil. Fig. 9. Scolex, dorsoventral view; holotype (BrX $65 \mathrm{f}-\mathrm{CHIOC} 37979 \mathrm{a})$; note the presence of two distinct parts of the metascolex. Fig. 10. Scolex, sagittal section; paratype (BrX $65 \mathrm{fz}-$ MHNG-PLAT 86723); note the presence of concentration of circular muscle fibres near sucker opening. Fig. 11. Pregravid proglottid, ventral view; paratype (BrX 65fz - MHNG-PLAT 86723). Abbreviations: ao - apical organ; $\mathrm{cm}$ - circular musculature; gc - glandular cells; lm - longitudinal musculature; mg - Mehlis' gland; oc - osmoregulatory canals; od - oviduct.

and density (Figs. 4-7). Proglottids covered with acicular filitriches (Fig. 8).

Inner longitudinal musculature well developed, formed by 1 row of numerous bundles of muscle fibres on dorsal and ventral side, with conspicuous concentration of bundles on lateral sides of proglottids (Figs. 13-17). Ventral osmoregulatory canals thin-walled, wide, median to lateral bands of vitelline follicles, slightly sinuous (Fig. 11). Dorsal osmoregulatory canals thick-walled, relatively wide, surrounded by vitelline follicles (Figs. 12-17). Another pair of tiny, thin-walled canals situated slightly dorsomedian to ventral canals, ventral to lateralmost lobes of ovary (Fig. 12); canals difficult to observe, may form anastomoses.

Testes numerous, spherical, small, 50-70 in diameter, in 3 irregular layers (Figs. 13, 14), 279-420 in number $(x=358, n=9)$. Testes form 3 fields more or less separated by median line of proglottids (uterine stem) and vaginal ca- nal with cirrus-sac and vas deferens (Fig. 11): aporal field with 145-220 testes, preporal field with 55-85 testes and postporal field with $79-116$ testes. Testes present also in gravid proglottids.

Vas deferens strongly coiled, with loops forming elongated field reaching to, but not crossing, median line of proglottid (Figs. 11, 14). Cirrus-sac elongate, thin-walled, slightly widened towards distal (terminal) part (Fig. 12), 395-505 long and 100-160 wide $(\mathrm{n}=31)$, its length representing $17-20 \%(x=18, n=31)$ of proglottid width. Sperm duct (internal vas deferens) strongly coiled (Fig. 12). Cirrus muscular, occupies up to $60 \%(n=30)$. Common genital atrium narrow, deep (Fig. 12). Genital pores alternating irregularly, markedly pre-equatorial, situated at $23-41 \%(\mathrm{x}=31, \mathrm{n}=31)$ of proglottid length from anterior margin (Fig. 11).

Ovary medullary, bilobed, follicular, with some dorsal follicles penetrating between bundles of inner longitudinal 


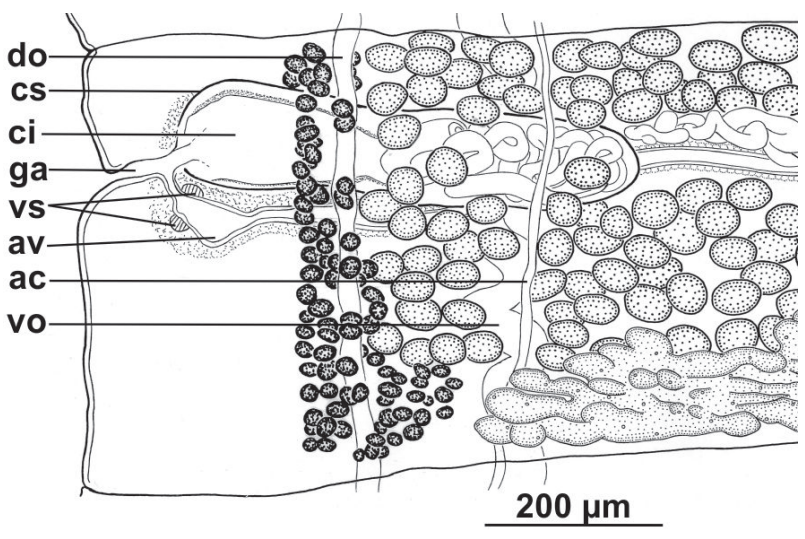

Fig. 12. Frezella vaucheri gen. $n$. et sp. n. from Tocantinsia piresi from Brazil. Terminal genitalia, dorsal view; paratype (BrX 65fz - MHNG-PLAT 86723). Abbreviations: ac - additional canal; av - asymmetrical chamber-like cavity of the vagina; ci - cirrus; cs - cirrus-sac; do - dorsal osmoregulatory canal; ga - genital atrium; vo - ventral osmoregulatory canal; vs - vaginal sphincter.

musculature to cortex (Fig. 15); length of ovary represents $24-37 \%$ of length of proglottid $(x=30, n=62)$, its width representing $65-77 \%$ of width of proglottid $(x=72, n=31$; Fig. 11). Mehlis' gland about $70-100$ in diameter, representing $4-7 \%$ of proglottid width $(n=11)$. Relative ovarian size (see de Chambrier et al. 2012) about $15 \%$ of size of mature and pregravid proglottids.

Vaginal canal slightly sinuous in proximal part, almost straight in distal part, often (in $68 \%$ of 40 proglottids observed) with asymmetrical chamber-like cavity near genital pore (Figs. 11, 12); terminal part of vaginal canal (pars copulatrix vaginae) surrounded by chromophilic cells, with small vaginal sphincter (Fig. 12). Vagina anterior (in $37 \%$ of proglottids counted) or posterior (in $63 \%$ of proglottids counted; $n=41$ ) to cirrus-sac. Vitelline follicles medullary, forming 2 long, dorsally uninterrupted, narrow lateral bands widened posteriorly at ovarian level (Figs. 11, 12). Length of bands represents $84-97 \%(\mathrm{x}=92 \%)$ and $84-98 \%(\mathrm{x}=91 \%)$ of length of proglottid on poral and aporal side, respectively $(n=31)$ (Fig. 11).

Uterus medullary, with development of type 1 (see de Chambrier et al. 2004a), i.e. uterine stem present as elongated longitudinal median concentration of chromophilic cells in immature proglottids, with lumen appearing in last immature proglottids. In mature proglottids, uterine stem thick-walled, with median lumen and short diverticula. In pregravid proglottids, uterine diverticula (lateral uterine branches) thin-walled, lined with few chromophilic cells. Uterus opens prematurely (precociously) by 1 elongate, slit-like pore.

Eggs spherical, outer envelope up to 65 in diameter; bilayered embryophore 16-17 in diameter, oncosphere 9-10 in diameter, embryonic hooks 6-7 long.

Type host: Tocantinsia piresi (Miranda Ribeiro) (Siluriformes: Auchenipteridae), vernacular name 'pocomão'; the only infected fish examined on 20 April 2013 was $39 \mathrm{~cm}$ long (total length; $31 \mathrm{~cm}$ standard length).
Type 1 o c a lity: Xingú River in Altamira, State of Pará, Brazil $\left(3^{\circ} 12^{\prime} \mathrm{S} ; 52^{\circ} 12^{\prime} \mathrm{W}\right)$.

Type material: Holotype (CHIOC 37978a-h - complete specimen and cross sections on eight slides), 5 paratypes including hologenophore (CHIOC 37979a-d, 37980a-d; IPCAS C-663; MHNG-PLAT 86723).

Site of infection: Anterior intestine.

Prevalence: 1 of 2 fish examined on 20 April 2013 infected (fish $20 \mathrm{~cm}$ long was uninfected); in September 2013, none of 6 fish (total length $35-42 \mathrm{~cm}$ ) harboured cestodes.

Ety mology: Specific name refers to Claude Vaucher, Switzerland, for his extraordinary contribution to cestode systematics.

Molecular identification: A fragment of $1563 \mathrm{bp}$ of the 28S RNA gene was amplified. The nucleotide sequence is available in the GenBank database (KM387399).

Remarks. Frezella vaucheri is the only species of the monotypic Frezella and thus it is characterised by the features listed in its Differential diagnosis (see above). This cestode is probably specific to Tocantinsia piresi, a poorly known auchenipterid catfish. The most characteristic feature of the new species and the new genus is the presence of a metascolex composed of two markedly different parts, which is unique in the Proteocephalinae. In scolex morphology, F. vaucheri somewhat resembles species of Brooksiella Rego, Chubb et Pavanelli, 1999, which also possess uniloculate suckers and a folded metascolex surrounding the suckers (predominantly posterior to the suckers in the new genus), but the metascolex is not divided as in Frezella (see figs. 9, 10 in de Chambrier et al. 2004b). In addition, Brooksiella praeputialis (Rego, Santos et Silva, 1974) has a much smaller body (12-22 $\mathrm{mm}$ vs 112 $122 \mathrm{~mm}$ ), weakly-developed internal longitudinal musculature and eggs with two polar projections (de Chambrier et al. 2004b). Peltidocotyle lenha (Woodland, 1933) has also the anterior part of the metascolex deeply folded (see fig. 104 in de Chambrier and Vaucher 1999) and the posterior part also bears few folds (see fig. 1 de Chambrier and Scholz 2008), but it possesses biloculate suckers and belong to a different subfamily, the Peltidocotylinae Woodland, 1934.

Among the proteocephalideans that parasitise auchenipterid catfishes (see Table 1), Nupelia tomasi de Chambrier et Vaucher, 1999 described from Trachelyopterus galeatus (Linnaeus) and Trachelyopterus cf. striatulus (Steindachner) in Paraguay resembles $F$. vaucheri in the possession of bundles of muscle fibres of the internal longitudinal musculature concentrated on the lateral sides of the body (see figs. 83 and 84 in de Chambrier and Vaucher 1999) and penetration of some ovarian follicles to the dorsal cortex (fig. 84 in de Chambrier and Vaucher 1999). However, $N$. tomasi, which belongs to the subfamily Nupeliinae Pavanelli et Rego, 1991 (see Rego 1994 for diagnosis of the subfamily), differs from the new species by numerous features, such as the absence of a metascolex and apical organ, markedly lower number of the testes (144-180 vs 279-420 in F. vaucheri) and the smaller size of the body (total length $42-72 \mathrm{~mm}$ vs $112-122 \mathrm{~mm}$; maximum width about $1.5 \mathrm{~mm}$ vs $2.8 \mathrm{~mm}$ ) (see de Chambrier and Vaucher 1999). 

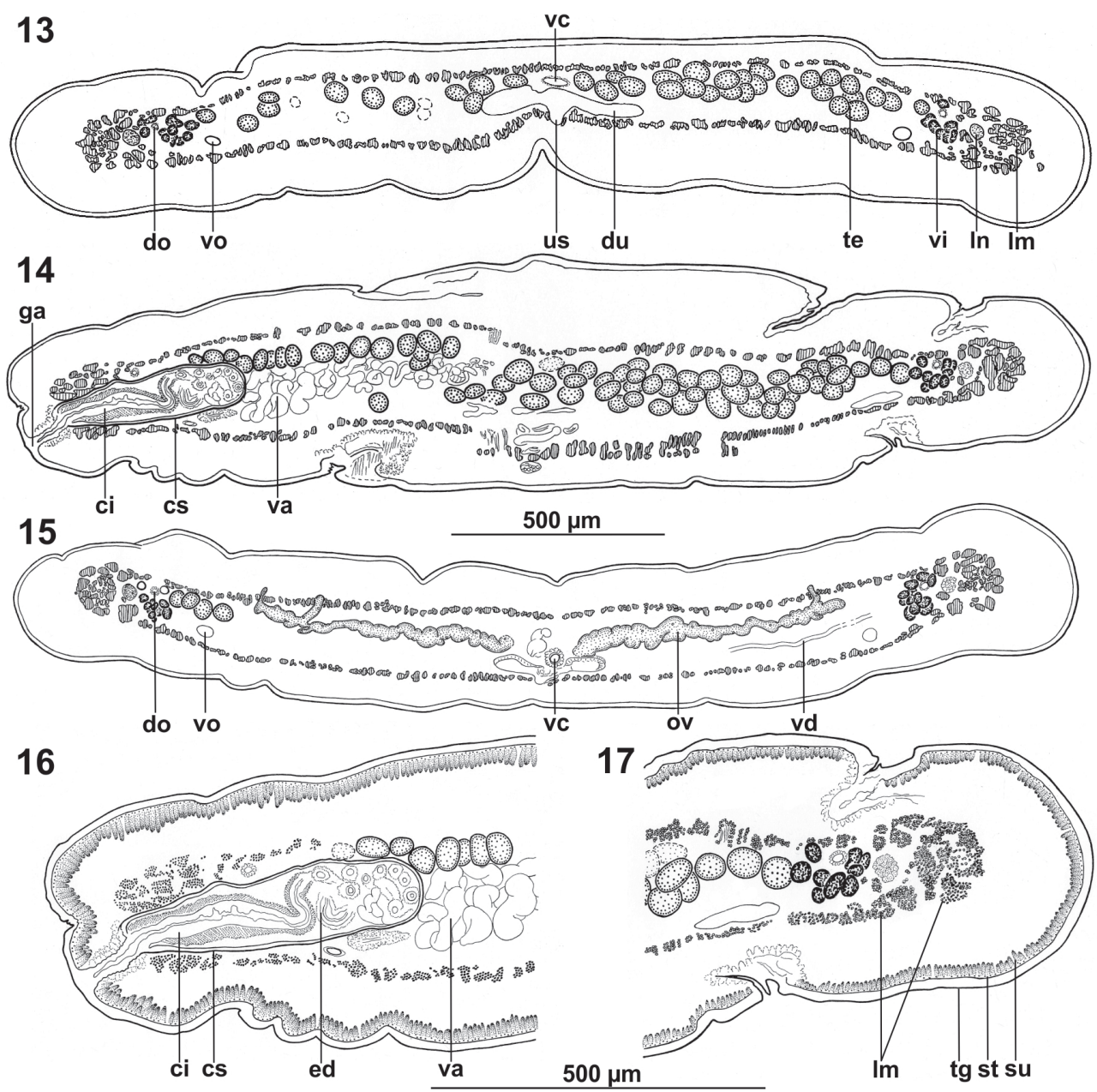

18
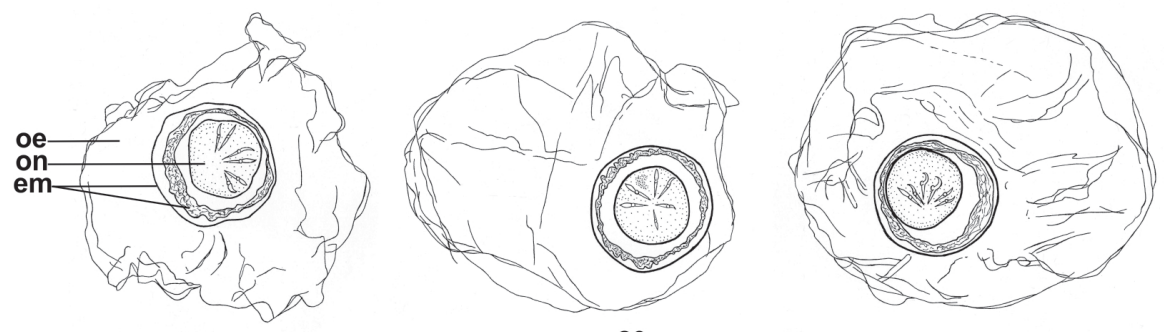

$20 \mu \mathrm{m}$

Fig. 13-18. Frezella vaucheri gen. n. et sp. n. from Tocantinsia piresi from Brazil. Fig. 13. Cross section at level of posterior part of proglottid; paratype (BrX 65z-MHNG-PLAT 86723). Figs. 14, 15. Cross sections at level of cirrus-sac and ovary, respectively; holotype (BrX 65f-CHIOC 37979c-d). Fig. 16. Cross section, detail of terminal genitalia; holotype (BrX 65f-CHIOC 37979c). Fig. 17. Crosssection, detail of aporal lateral region showing concentration of muscle fibres; holotype (BrX 65f - 37979e). Fig. 18. Eggs drawn in distilled water (BrX 65g - MHNG-PLAT 86722). Abbreviations: ci - cirrus; cs - cirrus-sac; do - dorsal osmoregulatory canal; du - diverticula of uterus; ed - ejaculatory duct; em - bilayered embryophore; ga - genital atrium; lm - internal longitudinal musculature; ln - longitudinal nerve cord; oe - outer envelope; on - oncosphere; ov - ovary; st - subtegumental muscle fibres; su - subtegumental cells; te - testes; tg - tegument; us - uterine stem; va - vas deferens; vc - vaginal canal; vd - vitelline duct; vi - vitelline follicles; vo - ventral osmoregulatory canal.

Scholzia emarginata (Diesing, 1850) (subfamily Proteocephalinae Woodland, 1933) from the redtail catfish, Phractocephalus hemioliopterus (Bloch et Schneider), in South America and Electrotaenia malopteruri (Fritsch, 1886) of the Gangesiinae Mola, 1929, from the electric catfish, Malapterurus electricus (Gmelin), in Africa also have a peculiar arrangement of the inner longitutinal musculature. In the former species, muscle fibres are more dense laterally similarly as it is in $F$. vaucheri, but the muscula- ture is much less developed in $S$. emarginata compared to the new species (see de Chambrier et al. 2005). In E. malopteruri, muscle fibres form a wide longitudinal band alongside the midline on the dorsal side of proglottids (see fig. 3d,e in de Chambrier et al. 2004c).

Several taxa of the subfamily Endorchiinae Woodland, 1934, such as Endorchis piraeeba Woodland, 1934 from the pimelodid catfish kumakuma, Brachyplatystoma filamentosum (Lichtenstein), and those of the Peltidocotyli- 
Table 1. Proteocephalidean tapeworms from auchenipterid catfishes.

\begin{tabular}{|c|c|c|c|c|}
\hline Subfamily & Species & Host & Distribution & References \\
\hline $\begin{array}{l}\text { Corallobothriinae } \\
\text { Freze, } 1965\end{array}$ & Corallotaenia sp. & $\begin{array}{l}\text { Ageneiosus pardalis } \\
\text { (Linnaeus) }\end{array}$ & MRB & Brooks and Deardorff (1980) \\
\hline \multirow[t]{2}{*}{$\begin{array}{l}\text { Endorchiinae } \\
\text { Woodland, } 1934\end{array}$} & $\begin{array}{l}\text { Endorchis auchenipteri } \\
\text { de Chambrier et Vaucher, } 1999\end{array}$ & $\begin{array}{l}\text { Auchenipterus osteomystax* } \\
\text { (Miranda Ribeiro) }\end{array}$ & $\mathrm{PRB}$ & de Chambrier and Vaucher (1999) \\
\hline & Endorchis sp. & $\begin{array}{l}\text { Trachelyopterus striatulus } \\
\text { (Steindachner) }\end{array}$ & PRB & de Chambrier and Vaucher (1999) \\
\hline \multirow[t]{2}{*}{$\begin{array}{l}\text { Monticelliinae } \\
\text { La Rue, } 1911\end{array}$} & $\begin{array}{l}\text { Ageneiella brevifilis } \\
\text { de Chambrier et Vaucher, } 1999\end{array}$ & $\begin{array}{l}\text { Ageneiosus inermis* } \\
\text { (Linnaeus), } \\
\text { A. militaris } \\
\text { Valenciennes }\end{array}$ & PRB & $\begin{array}{l}\text { de Chambrier and Vaucher (1999), } \\
\text { Gil de Pertierra (2009) }\end{array}$ \\
\hline & $\begin{array}{l}\text { Goezella danbrooksi } \\
\text { de Chambrier, Rego et Mariaux, } 2004\end{array}$ & $\begin{array}{l}\text { Ageneiosus pardalis* } \\
\text { (Linnaeus) }\end{array}$ & MRB & $\begin{array}{l}\text { Brooks and Deardorff (1980), } \\
\text { de Chambrier et al. (2004b) }\end{array}$ \\
\hline $\begin{array}{l}\text { Nupeliinae } \\
\text { Pavanelli et Rego, } 1991\end{array}$ & $\begin{array}{l}\text { Nupelia tomasi } \\
\text { de Chambrier et Vaucher, } 1999\end{array}$ & $\begin{array}{l}\text { Trachelyopterus galeatus* } \\
\text { (Linnaeus), } \\
\text { T. cf. striatulus } \\
\text { (Steindachner) }\end{array}$ & PRB & de Chambrier and Vaucher (1999) \\
\hline $\begin{array}{l}\text { Peltidocotylinae } \\
\text { Woodland, } 1934\end{array}$ & $\begin{array}{l}\text { Luciaella ivanovae } \\
\text { Gil de Pertierra, } 2009\end{array}$ & Ageneiosus inermis* & PRB & Gil de Pertierra (2009) \\
\hline \multirow[t]{2}{*}{$\begin{array}{l}\text { Proteocephalinae } \\
\text { La Rue, } 1911\end{array}$} & $\begin{array}{l}\text { Cangatiella arandasi } \\
\text { Pavanelli et Machado dos Santos, } 1991\end{array}$ & Trachelyopterus galeatus* & PRB & Pavanelli and Machado dos Santos (1991) \\
\hline & Frezella vaucheri gen. n. et sp. n. & Tocantinsia piresi* & A & Present study \\
\hline \multirow[t]{2}{*}{$\begin{array}{l}\text { Zygobothriinae } \\
\text { Woodland, } 1933\end{array}$} & $\begin{array}{l}\text { Gibsoniela mandube } \\
\text { (Woodland, 1935) }\end{array}$ & Ageneiosus inermis* & $\mathrm{A}, \mathrm{PRB}$ & $\begin{array}{l}\text { Woodland (1935), } \\
\text { Rego (1984, 1992), } \\
\text { de Chambrier and Vaucher (1999) }\end{array}$ \\
\hline & $\begin{array}{l}\text { Gibsoniela meursaulti } \\
\text { de Chambrier et Vaucher, } 1999\end{array}$ & $\begin{array}{l}\text { Ageneiosus inermis*, } \\
\text { A. militaris }\end{array}$ & A, PRB & $\begin{array}{l}\text { Woodland (1935), } \\
\text { Rego (1992), } \\
\text { de Chambrier and Vaucher (1999) }\end{array}$ \\
\hline
\end{tabular}

* type host; MRB - Magdalena River basin; PRB - Paraná River basin; A - Amazon.

nae, e.g. Luciaella ivanovae Gil de Pertierra, 2009 from the auchenipterid Ageneiosus inermis (Linnaeus), resemble the new cestode in the presence of some dorsal ovarian follicles in the cortex (see de Chambrier and Vaucher 1997 and fig. 1E in Gil de Pertierra 2009). However, the former species can be easily distinguished from $F$. vaucheri by the cortical position of vitelline follicles (Rego 1994).

The presence of a chamber-like enlargement of the distal (external) part of the vaginal canal, which was observed in two thirds of proglottids in F. vaucheri, is rare among proteocephalidean cestodes. The terminal part of the vagina of Mariauxiella pimelodi de Chambrier et Rego, 1995, a parasite of Pimelodus ornatus Kner and Pimelodus sp. from Brazil, is also enlarged, but symmetrically (see fig. 4 in de Chambrier and Rego 1995) unlike that of $F$. vaucheri, which is often asymmetrical (Figs. 11, 12).

The precocious uterine aperture, which is present in $F$. vaucheri, has been reported in proteocephalideans parasitising reptiles, such as species of Crepidobothrium Monticelli, 1899 and Testudotaenia Freze, 1965, in which the eggs are laid immature through a longitudinal aperture in pregravid proglottids (see de Chambrier 1988, 1989a,b, de Chambrier et al. 2009).

The high number of the testes is a good discriminant character for the new taxon. Only Thaumasioscolex didelphidis Cañeda-Guzmán, de Chambrier et Scholz, 2001 has more testes than $F$. vaucheri (432-548 vs 279-420) among the Proteocephalidea (Cañeda-Guzmán et al. 2001). A few other species from different subfamilies have a similar number of the testes, e.g. Proteocephalus paraguayensis (Rudin, 1917) (238-344 testes), Monticellia ventrei de Chambrier et Vaucher, 1999 (222-325), Nomimoscolex ad- monticellia Woodland, 1934 (323-372) and Rudolphiella szidati Gil de Pertierra et de Chambrier, 2000 (289-365) (Woodland 1934, de Chambrier 1990, de Chambrier and Vaucher 1999, Gil de Pertierra and de Chambrier 2000).

The presence of a circular musculature in the suckers is common in several unrelated proteocephalidean taxa and four types can be distinguished on the basis of its shape (de Chambrier et al. 2009). In this characteristic, the new taxon resembles most closely those species that have the circular musculature only slightly developed, such as Brooksiella praeputialis (Zygobothriinae) from the cetopsid Cetopsis caecutiens Spix et Agassiz (Cetopsidae) and Rudolphiella szidati Gil de Pertierra et de Chambrier, 2000 (Rudolphiellinae Woodland, 1933) from Luciopimelodus pati (Valenciennes) (Pimelodidae) in the Neotropical Region (Rego et al. 1999, Gil de Pertierra and de Chambrier 2000, de Chambrier et al. 2004b).

\section{DISCUSSION}

Scolex morphology has played a key role in circumscription of genera or even subfamilies of proteocephalidean cestodes (see, e.g. Acanthotaeniinae Freze, 1963; Corallobothriinae Freze, 1965; Gangesiinae Mola, 1929, etc. - Freze 1965, Rego 1994, de Chambrier et al. 2003). Many of these taxa possess a metascolex and the presence/ absence of this structure was considered to be the most important diagnostic character in classification of all proteocephalideans (Rego 1999). Even though molecular phylogenetic studies (de Chambrier et al. 2004a, Hypša et al. 2005, Scholz et al. 2011) have demonstrated homoplastic character of this morphological structure, the presence of a metascolex, its form and structure are of taxonomic im- 
portance at least at the generic and species level (see, e.g. de Chambrier and Vaucher 1999, Coquille and de Chambrier 2008, Scholz et al. 2013).

Brooks and Rasmussen (1984) distinguished three different types of the metascolex within the Proteocephalidea: (1) formed by an enlargement of the proliferation zone (neck), e.g. Choanoscolex abscisus (Riggenbach, 1896) (see fig. 35 in Rego 1999); (2) formed by proliferation of the tissue around each sucker, e.g. Brooksiella praeputialis (see figs. 9, 10 in de Chambrier et al. 2004b); and (3) formed by proliferation of the scolex tissue around the base of the suckers, e.g. Amphoteromorphus piraeeba Woodland, 1934 (see figs. 18, 19 in de Chambrier and Vaucher 1997).

The metascolex of Frezella vaucheri somewhat resembles types 2 (some folds are present around the suckers, mainly their posterior parts) and 3 (scolex tissue is proliferated around the base of the suckers). In fact, this metascolex can be considered to represent another type, which is characterised by division of the metascolex into two zones, with the anterior one strongly wrinkled and the posterior one sparsely folded (Fig. 1). Among all species of Proteocephalidea, Spatulifer maringaensis Pavanelli et Rego, 1989 and Peltidocotyle lenha have a somewhat similar metascolex, which consists of two zones.

As far as the authors are aware, there are no data on the parasites of Tocantinsia piresi, which occurs in the Amazon and Tocantins River basins (Barros 2012, Froese and Pauly 2014). This fish has a nocturnal omnivorous behaviour (feeds mainly on fruits and seeds) and its feeding behaviour is directly affected by the hydrologic cycle, i.e. wet and dry seasons (Carvalho and de Resende 1984), which may influence the seasonality in the occurrence and maturation of its parasites. Frezella vaucheri thus represents the first parasite reported from this poorly known fish and the 11th proteocephalidean described from auchenipterid catfishes (Table 1).

Based on a molecular phylogenetic study of tetraphyllidean-like cestodes of elasmobranchs, Caira et al. (2014) proposed a new order, Onchoproteocephalidea, to accommodate several taxa from elasmobranchs previously placed in the tetraphyllidean family Onchobothriidae Braun, 1900 and the entire order Proteocephalidea Mola, 1928. However, this new order was not sufficiently circumscribed and no morphological synapomorphies were provided in its brief diagnosis. In addition, this diagnosis contains some errors, such as the presence of a spined cirrus ("Cirrus armed with spinitriches"; in fact, the cirrus is unspined in proteocephalideans, the only exception being Euzetiella tetraphylliformis de Chambrier, Rego et Vaucher, 1999 - see de Chambrier et al. 1999) and the scolex with four muscular bothridia (majority of proteocephalideans possess spherical suckers or acetabula indistinguishable from those in cyclophyllidean cestodes). A putative synapomorphy, i.e. the presence of simple gladiate microtriches, is also questionable and has to be verified because detailed data on surface ultrastructure are available for only about 30 species of proteocephalideans (out of more than 300 nominal species - Arredondo et al. 2014).

Even though relatedness of proteocephalideans with some of the 'hooked' tetraphyllidean-like cestodes such as those of Acanthobothrium van Beneden, 1849 is not questioned, the taxonomic proposal of the order Onchoproteocephalidea is considered to be premature and not justified sufficiently because a thorough comparative taxonomic study of morphologically quite distinct taxa was not carried out. For the reasons listed above, the Proteocephalidea is retained as a valid order in the present paper, but future systematic studies should focus on a comparative analysis of the taxa that form the monophyletic lineage for which Caira et al. (2014) proposed the new order.

Acknowledgements. The authors are indebted to Aldenice de Nazaré Pereira, Fabiano Paschoal and Felipe Bisaggio Pereira for invaluable help with collection and dissection of fish. Thanks are also due to Jan Brabec for help with sequencing and analysing sequences, Roman Kuchta (both České Budějovice) and André Puiz (Geneva) for SEM micrographs, to Janik Pralong and Gilles Roth (Natural History Museum, Geneva) for their technical help and to Emil José Hernández Ruz (Universidade Federal do Pará - Campus Altamira) for providing the facilities during the field trip. The senior author thanks Jean Mariaux for welcome him in the Natural History Museum, Geneva. This study was supported by the 'Ciência sem fronteiras' Brazilian program - visitant researcher modality (No. 135/2012) (stay of T. S. in Brazil at the Universidade Federal Rural de Rio de Janeiro), Conselho Nacional de Desenvolvimento Científico e Tecnológico (CNPq) grants to José Luis Luque (Nos. 474077/2011-0, 304254/2011-8, 402665/20120); the National Science Foundation (PBI awards Nos. 0818696 and 0818823), Institute of Parasitology (institutional support RVO 60077344) and Czech Science Foundation (P505/12/G112). P.V.A. was supported by postgraduate fellowship from CNPq.

\section{REFERENCES}

Arredondo N.J., de Chambrier A., Gil de Pertierra A.A. 2013: A new genus and species of the Monticelliinae (Eucestoda: Proteocephalidea), a parasite of Pseudoplatystoma fasciatum (Pisces: Siluriformes) from the Paraná River Basin (Argentina), with comments on microtriches of proteocephalideans. Folia Parasitol. 60: 248-256.

Arredondo N.J., Gil de Pertierra A.A. 2012: Margaritaella gracilis gen. n. et sp. n. (Eucestoda: Proteocephalidea), a parasite of Callichthys callichthys (Pisces: Siluriformes) from the Paraná River basin, Argentina. Folia Parasitol. 59: 99-106.

Arredondo N.J., Gil de Pertierra A.A., de Chambrier A. 2014: A new species of Pseudocrepidobothrium (Cestoda: Pro- teocephalidea) from Pseudoplatystoma fasciatum (Pisces: Siluriformes) in the Paraná River basin (Argentina). Folia Parasitol. 61: 462-472.

Ash A., Scholz T., de Chambrier A., Brabec J., Oros M., Kar P.K., Chavan S., Mariaux J. 2012. Revision of Gangesia (Cestoda: Proteocephalidea) in the Indomalayan Region: morphology, molecules and surface ultrastructure. PLoS ONE 7: e46421.

BArros F.B. 2012: Etnoecologia da pesca na Reserva Extrativista Riozinho do Anfrísio - Terra do Meio, Amazônia, Brasil. Amazônica 4: 286-312. 
Brooks D.R., Deardorff, T.L. 1980: Three proteocephalid cestodes from Columbian Siluriformes fishes, including Nomimoscolex alovarius sp. n. (Monticelliidae: Zygobothriinae). Proc. Biol. Soc. Wash. 47: 15-21.

Brooks D.R., Rasmussen G. 1984: Proteocephalid cestodes from Venezuelan catfish, with a new classification of the Monticelliidae. Proc. Biol. Soc. Wash. 97: 748-760.

Caira J.N., Jensen K., Waeschenbach A., Olson P.D., LitTLEWOOD D.T.J. 2014: Orders out of chaos - molecular phylogenetics reveals the complexity of shark and stingray tapeworm relationships. Int. J. Parasitol. 44: 55-73.

Cañeda-Guzmán I.C., de Chambrier A., Scholz T. 2001: Thaumasioscolex didelphidis $\mathrm{n}$. gen. and n. sp. (Eucestoda: Proteocephalidae) from the black-eared opossum Didelphis marsupialis from Mexico, the first proteocephalidean tapeworm from a mammal. J. Parasitol. 87: 639-647.

Carvalho F.M., De Resende E.K. 1984: Aspectos da biologia de Tocantinsia depressa (Siluriformes, Auchenipteridae). Amazoniana 8: 327-337.

De Chambrier A. 1988: Crepidobothrium garzonii n. sp. (Cestoda: Proteocephalidae) parasite de Bothrops alternatus Dum. Bibr. \& Dum., 1854 (Serpentes: Viperidae) au Paraguay. Rev. Suisse Zool. 95: 1163-1170.

De Chambrier A. 1989a: Revision du genre Crepidobothrium Monticelli, 1900 (Cestoda: Proteocephalidae) parasite d'ophidiens néotropicaux. I. C. gerrardii (Baird, 1860) et C. viperis (Beddard, 1913). Rev. Suisse Zool. 96: 191-217.

De Chambrier A. 1989b: Revision du genre Crepidobothrium Monticelli, 1900 (Cestoda: Proteocephalidae) parasite d'ophidiens néotropicaux. 2. Crepidobothrium dollfusi Freze, 1965, Crepidobothrium lachesidis (MacCallum, 1921) and conclusions. Rev. Suisse Zool. 96: 345-380.

de Chambrier A. 1990: Redescription de Proteocephalus paraguayensis (Rudin, 1917) (Cestoda: Proteocephalidae) parasite de Hydrodynastes gigas (Dum., Bibr. \& Dum., 1854) du Paraguay. Syst. Parasitol. 16: 85-97.

De Chambrier A. 2001: A new tapeworm from the Amazon, Amazotaenia yvettae n. gen., n. sp., (Eucestoda: Proteocephalidea) from the siluriform fishes Brachyplatystoma filamentosum and B. vaillanti (Pimelodidae). Rev. Suisse Zool. 108: 303-316.

de Chambrier A., Al Kallak S.N.H., Mariaux J. 2003: A new tapeworm Postgangesia inarmata sp. n. (Eucestoda: Proteocephalidea: Gangesiinae), parasite of Silurus glanis (Siluriformes) from Iraq and some considerations on Gangesiinae. Syst. Parasitol. 55: 199-209.

de Chambrier A., Binh T. T., Scholz T. 2012: Ophiotaenia bungari $\mathrm{n}$. sp. (Cestoda), a parasite of Bungarus fasciatus (Schneider) (Ophidia: Elapidae) from Vietnam, with comments on relative ovarian size as a new and potentially useful diagnostic character for proteocephalidean tapeworms. Syst. Parasitol. 81: $39-50$.

de Chambrier A., Coquille S.C., Tkach V., Mariaux J. 2009: Redescription of Testudotaenia testudo (Magath, 1924) (Eucestoda: Proteocephalidea), a parasite of Apalone spinifera (Le Sueur) (Reptilia: Trionychidae) and Amia calva L. (Pisces: Amiidae) in North America and erection of Testudotaeniinae $n$. subfam. Syst. Parasitol. 73: 49-64.

de Chambrier A., Rego A.A. 1995: Mariauxiella pimelodi $\mathrm{n} . \mathrm{g}$., n. sp. (Cestoda: Monticelliidae): a parasite of pimelodid siluroid fishes from South America. Syst. Parasitol. 30: 57-65.

de Chambrier A., Rego A.A., Gil de Pertierra A.A. 2005 Redescription of two cestode parasites (Eucestoda: Proteocephalidea), parasites of Phractocephalus hemioliopterus (Siluriformes) from the Amazon and proposition of Scholzia gen. n. Rev. Suisse Zool. 112: 735-752.

de Chambrier A., Rego A.A., Mariaux J. 2004b: Redescription of Brooksiella praeputialis and Goezeella siluri (Eucestoda: Proteocephalidea), parasites of Cetopsis coecutiens (Siluriformes) from the Amazon and proposition of Goezeella danbrooksi sp. n. Rev. Suisse Zool. 111: 111-120.
De Chambrier A., Rego A.A., Vaucher C. 1999: Euzetiella tetraphylliformis n. gen., n. sp., (Eucestoda: Proteocephalidae), parasite du poisson d'eau douce néotropical Paulicea luetkeni (Siluriformes, Pimelodidae). Parasite 6: 43-47.

de Chambrier A., Scholz T. 2008: Tapeworms (Cestoda: Proteocephalidea) of firewood catfish Sorubimichthys planiceps (Siluriformes: Pimelodidae) from the Amazon River. Folia Parasitol. 55: 17-28.

De Chambrier A., Scholz T., Ibraheem M.H. 2004c: Redescription of Electrotaenia malopteruri (Fritsch, 1886) (Cestoda: Proteocephalidae), a parasite of Malapterurus electricus (Siluriformes: Malapteruridae) from Egypt. Syst. Parasitol. 57: 97-109.

de Chambrier A., Scholz T., Kuchta R. 2014: Taxonomic status of Woodland's enigmatic tapeworms (Cestoda: Proteocephalidea) from Amazonian catfishes: back to museum collections. Syst. Parasitol. 87: 1-19.

de Chambrier A., Scholz T., Kuchta R., Posel P., Mortenthaler M., Chuquipiondo Guardia C. 2006: Tapeworms (Cestoda: Proteocephalidea) of fish from the Amazon River in Peru. Comp. Parasitol. 73: 111-120.

de Chambrier A., Vaucher C. 1997: Révision des cestodes (Monticelliidae) décrits par Woodland (1934) chez Brachyplatystoma filamentosum avec redéfinition des genres Endorchis Woodland, 1934 et Nomimoscolex Woodland, 1934. Syst. Parasitol. 37: 219-233.

de Chambrier A., Vaucher C. 1999: Proteocephalidae et Monticelliidae (Eucestoda: Proteocephalidea) parasites de poissons d'eau douce du Paraguay avec descriptions d'un genre nouveau et de dix espèces nouvelles. Rev. Suisse Zool. 106: 165-240.

de Chambrier A., Zehnder M.P., Vaucher C., Mariaux J. 2004a: The evolution of the Proteocephalidea (Platyhelminthes, Eucestoda) based on an enlarged molecular phylogeny, with comments on their uterine development. Syst. Parasitol. 57: 159-171.

Chervy L. 2009: Unified terminology for cestode microtriches: a proposal from the international workshops on cestode systematics in 2002-2008. Folia Parasitol. 56: 199-230.

Coquille S.C., De Chambrier A. 2008: Cairaella henrii gen. n. sp. n., a parasite of Norops trachyderma (Polychrotidae), and Ophiotaenia nicoleae sp. n. (Eucestoda: Proteocephalidea), a parasite of Thecadactylus rapicauda (Gekkonidae) in Ecuador. Folia Parasitol. 55: 197-206.

Froese R., Pauly D. (Eds.) 2014: FishBase. World Wide Web electronic publication, www.fishbase.org, 06/2014.

Freze V.I. 1965: Essentials of Cestodology. Vol. V. Proteocephalata in Fish, Amphibians and Reptiles. Nauka, Moscow, 538 pp. (In Russian; English translation, Israel Program of Scientific Translation, 1969, Cat. No. 1853. v + 597 pp.)

Gil de Pertierra A.A. 2009: Luciaella ivanovae n. g., n. sp. (Eucestoda: Proteocephalidea: Peltidocotylinae), a parasite of Ageneiosus inermis (L.) (Siluriformes: Auchenipteridae) in Argentina. Syst. Parasitol. 73: 71-80.

Gil de Pertierra A.A., De Chambrier A. 2000: Rudolphiella szidati n. sp. (Proteocephalidea: Monticelliidae, Rudolphiellinae) parasite of Luciopimelodus pati (Valenciennes, 1840) (Pisces: Pimelodidae) from Argentina and new observations on Rudolphiella lobosa (Riggenbach, 1895). Rev. Suisse Zool. 107: 81-95.

HypšA V., Š́eř́íkovÁ A., Scholz T. 2005: Multigene analysis and secondary structure characters in a reconstruction of phylogeny, evolution and host-parasite relationship of the order Proteocephalidea (Eucestoda). Parasitology 130: 359-371.

Mees G.F. 1974: The Auchenipteridae and Pimelodidae of Suriname (Pisces, Nematognathi). Zool. Verhandel. 132: 1-256.

Mees G.F. 1984: A note on the genus Tocantinsia (Pisces, Nematognathi, Auchenipteridae). Amazoniana 9: 31-34.

Miranda Ribeiro A. 1920: Peixes (excl. Characinidae). Comissão de Linhas Telegraphicas Estratégicas de Matto-Grosso ao Amazonas, Annexo $\mathrm{n}^{\circ} 5$ (Historia Natural: Zoologia) 58: 1-15. 
Oros M., Scholz T., Hanzelová V., Mackiewick J.S. 2010: Scolex morphology of monozoic cestodes (Caryophyllidea) from the Palaearctic Region: a useful tool for species identification. Folia Parasitol. 57: 37-46.

Pavanelli G.C., Machado dos Santos M.H. 1991: Cangatiella arandasi gen. n., sp. n. (Cestoda: Proteocephalidae), parasito de Parauchenipterus galeatus (Siluriformes: Auchenipteridae) do Rio Parana. Rev. Bras. Biol. 7: 535-539.

Rego A. A. 1984: Proteocephalidea from Amazonian freshwater fishes: new systematic arrangement for the species described by Woodland as Anthobothrium (Tetraphyllidea). Acta Amazon. 14: 86-94.

Rego A.A. 1992: Redescription of Gibsoniela mandube (Woodland, 1935) (Cestoda: Proteocephalidae), a parasite of Ageneiosus brevifilis (Pisces: Siluriformes) and reappraisal of the classification of the proteocephalideans. Mem. Inst. Oswaldo Cruz 87: 417-422.

Rego A.A. 1994: Order Proteocephalidea Mola, 1928. In: L.F. Khalil, A. Jones and R.A. Bray (Eds.), Keys to the Cestode Parasites of Vertebrates. CAB International, Wallingford, pp. 257-293.

Rego A.A. 1999: Scolex morphology of proteocephalid cestodes parasites of Neotropical freshwater fishes. Mem. Inst. Oswaldo Cruz 94: 37-52.

Rego A.A., Chubb J.C., Pavanelli G.C. 1999: Cestodes in South American freshwater teleost fishes: keys to genera and brief description of species. Rev. Bras. Zool. 16: 299-367.

ReIs R.E. 2013: Conserving the freshwater fishes of South America. Int. Zoo Yb. 47: 65-70.

SCHмIDT G.D. 1986: CRC Handbook of Tapeworm Identification. CRC Press Inc., Boca Raton, Florida, 675 pp.

Scholz T., de Chambrier A., Kuchta R., Littlewood D.T.J., Waeschenbach A. 2013: Macrobothriotaenia ficta (Cestoda: Proteocephalidea), a parasite of sunbeam snake (Xenopeltis unicolor): example of convergent evolution. Zootaxa 3640: 485499.

Scholz T., De Chambrier A., Mariaux J., Kuchta R. 2011: Redescription of Corallobothrium solidum (Cestoda: Proteocephalidea) and erection of a new genus, Essexiella, for tapeworms from channel catfish (Ictaluridae). J. Parasitol. 97: 11421151.

Woodland W.N.F. 1934: On the Amphilaphorchidinae, a new subfamily of proteocephalid cestodes, and Myzophorus admonticellia, gen. and sp. n., parasitic in Pirinampus spp. from the Amazon. Parasitology 26: 141-149.

Woodland W.N.F. 1935: Some more remarkable cestodes from Amazon siluroids fish. Parasitology 27: 207-225.

Cite this article as: Alves P.V., de Chambrier A., Scholz T., Luque J.L. 2015: A new genus and species of proteocephalidean tapeworm (Cestoda), first parasite found in the driftwood catfish Tocantinsia piresi (Siluriformes: Auchenipteridae) from Brazil. Folia Parasitol. 62: 006. 